\title{
The Methodology Applied in DPPH, ABTS and Folin-Ciocalteau Assays Has a Large Influence on the Determined Antioxidant Potential
}

\author{
Helena Abramovič, Blaž Grobin, Nataša Poklar Ulrih and Blaž Cigić* \\ Department of Food Science and Technology, Biotechnical Faculty, University of Ljubljana, Jamnikarjeva 101, \\ 1000 Ljubljana, Slovenia \\ * Corresponding author: E-mail: blaz.cigic@bf.uni-lj.si \\ Phone: +38613203784 Fax: +38612566296
}

Received: 29-03-2017

\begin{abstract}
Antioxidant potential (AOP) is not only the property of the matrix analyzed but also depends greatly on the methodology used. The chromogenic radicals 2,2'-azino-bis(3-ethylbenzothiazoline-6-sulfonic acid) (ABTS ${ }^{\bullet+}$ ), 2,2-diphenyl-1-picrylhydrazyl ( $\left.\mathrm{DPPH}^{*}\right)$ and Folin-Ciocalteu (FC) assay were applied to estimate how the method and the composition of the assay solvent influence the AOP determined for coffee, tea, beer, apple juice and dietary supplements. Large differences between the AOP values depending on the reaction medium were observed, with the highest AOP determined mostly in the FC assay. In reactions with chromogenic radicals several fold higher values of AOP were obtained in buffer $\mathrm{pH} 7.4$ than in water or methanol. The type of assay and solvent composition have similar influences on the reactivity of a particular antioxidant, either pure or as part of a complex matrix. The reaction kinetics of radicals with antioxidants in samples reveals that AOP depends strongly on incubation time, yet differently for each sample analyzed and the assay applied.
\end{abstract}

Keywords: Chromogenic radicals, antiradical activity, Folin-Ciocalteu, reaction kinetics, Trolox equivalents, solvent composition

\section{Introduction}

A dozen different methods can be found in the literature $^{1}$ for in vitro analysis of antioxidant properties of phenolic compounds. Among the most popular are those employing phospho-tungsto-molybdate in Folin-Ciocalteu (FC) reagent or chromogenic radicals such as $2,2^{\prime}$-azino-bis(3-ethylbenzothiazoline-6-sulfonic acid) $\left(\mathrm{ABTS}^{\circ+}\right)$ and 2,2-diphenyl-1-picrylhydrazyl (DPPH $\left.{ }^{\circ}\right)$. Such radicals, with unpaired valence electron at one nitrogen atom, can be reduced by compounds with antioxidant properties and the assays are based on spectrophotometric measurements of unreacted radicals at the beginning and after a certain incubation time.

There is a long going debate as to whether results of such in vitro assays are relevant, since no correlation between in vitro antioxidant properties and health benefits has been confirmed ${ }^{2}$ and rates of reaction of antioxidants with radicals are much more important for their effective- ness than the stoichometric values obtained by antioxidant assays. ${ }^{3,4}$ Despite these limitations a great number of papers are published each year containing data about antioxidant potential (also activity and capacity) and total polyphenol content of various biological, pharmaceutical and food samples.

The incubation time for reaction of antioxidants with radical probe and FC reagent varies substantially between different studies and ranges from minutes to hours. Apart from their structural characteristics (number and position of $-\mathrm{OH}$ groups, inductive effects of other substituents present in the antioxidant molecule, steric hindrance/accessibility, packaging of an antioxidant around reactive species) the reactivity of an antioxidant depends significantly on reaction conditions such as solvent polarity, $\mathrm{pH}$, temperature, type and concentration of reactive species. ${ }^{3,6-14}$ Since the selection of the method, the time and reaction conditions adopted to evaluate the content of antioxidants in a given sample significantly 
impact the determined values and, due to the fact that these parameters in a number of articles are relatively poorly described, it is very difficult to compare the results of AOP obtained for similar samples in different studies.

As shown in numerous studies, green and black tea, green and roasted coffee, apple juice, beer, and cranberry fruits are considered as antioxidant rich foods and exhibit notable AOP. ${ }^{15-20}$ The primary purpose of the present study was to demonstrate how the selected method and composition of the assay solvent influence the reactivity of antioxidant compounds in the above mentioned foods with chromogenic radicals, $\mathrm{DPPH}^{*}$ and $\mathrm{ABTS}^{\circ+}$, and with the FC reagent. The reactivity was evaluated utilizing the approach of reaction kinetics as well as stoichiometric calculations of AOP expressed in Trolox equivalents (TE). ABTS assay was carried out in water and in aqueous buffers $\mathrm{pH} 7.4$ and $\mathrm{pH}$ 5.0. DPPH assay was performed in methanol $(\mathrm{MeOH})$ and in mixtures of $\mathrm{MeOH}$ with water and aqueous buffers $\mathrm{pH} 7.4$ and $\mathrm{pH}$ 5.0. FC assay was carried out only after one protocol.

\section{Experimental}

\section{1. Sample Material}

The samples included in our investigation: green tea (Green tea, Winston's Tea Company, UK), black tea (English breakfast, Winston's Tea Company, UK), green coffee (Finca la Providencia, 100\% Arabica, Guatemala), roasted coffee (Green coffee roasted for 13 minutes, final temperature $223{ }^{\circ} \mathrm{C}$; STA Impianti - Combi5), apple juice (100\%, Fructal, Slovenia), beer (Pale lager, Union, Slovenia), dried cranberries (Brusnifem, Medex, Slovenia) and dried cranberries with added vitamin C (Cranberry kapseln mit vitamin C, Sunlife productions, Germany), were obtained from local suppliers.

\section{2. Preparation of Sample Solutions}

Coffee beans were ground using a laboratory scale mill and sieved through a No. 30 sieve. Crushed tea leaves were additionally homogenised in a mortar. $6.00 \mathrm{~g}$ of ground green or roasted coffee, and $1.00 \mathrm{~g}$ of green or black tea were transferred into a beaker and $100 \mathrm{ml}$ boiling MilliQ water poured over. The beaker was covered with a watch glass to minimize evaporation and the suspension was mixed on a magnetic stirrer (300 rpm) for 5 min. Small amounts of evaporated water were compensated by MilliQ water (control by weighing). $100 \mathrm{mg}$ of dietary supplement (dried cranberries, dried cranberries with added vitamin C) were transferred into a $15 \mathrm{ml}$ centrifuge tube and extracted with $10.0 \mathrm{~mL}$ of MilliQ water by vortexing at room temperature for $5 \mathrm{~min}$. All samples were filtered through $0.45-\mu \mathrm{m}$ cellulose acetate filters and used for the analysis of AOP within $1 \mathrm{~h}$. Beer and apple juice were transferred from freshly opened packages.

\section{3. Reagents and Solvents}

ABTS reagent, $\mathrm{DPPH}^{\circ}$ reagent, Folin-Ciocalteu reagent, Trolox and ethanol $\left(\mathrm{C}_{2} \mathrm{H}_{5} \mathrm{OH}, 96 \%\right)$ were purchased from Sigma-Aldrich $\mathrm{GmbH}$ (Steinheim, Germany). Methanol $\left(\mathrm{CH}_{3} \mathrm{OH}, 99.9 \%\right)$, sodium carbonate $\left(\mathrm{Na}_{2} \mathrm{CO}_{3}\right)$, sodium hydroxide $(\mathrm{NaOH})$, acetic acid $\left(\mathrm{CH}_{3} \mathrm{COOH}\right)$ and sodium dihydrogen phosphate dihydrate $\left(\mathrm{NaH}_{2} \mathrm{PO}_{4} \times 2 \mathrm{H}_{2} \mathrm{O}\right)$ were obtained from Merck (Darmstadt, Germany). Manganese dioxide $\left(\mathrm{MnO}_{2}\right)$ was obtained from Kemika (Zagreb, Croatia). The water used was purified using a Milli$\mathrm{Q}$ system (resistivity $>18 \mathrm{M} \Omega \mathrm{cm}$; Millipore).

\section{4. Folin-Ciocalteau Assay}

The FC assay was performed according to the modification of Gutfinger. ${ }^{21} 50 \mu \mathrm{L}$ of appropriately diluted sample, $700 \mu \mathrm{L}$ of MilliQ water and $125 \mu \mathrm{L}$ of FC reagent (previously diluted 1:2(v/v) with MilliQ water) were transferred into a $1.5 \mathrm{~mL}$ microcentrifuge tube and mixed by vortexing. After $5 \mathrm{~min}$ of incubation at $25^{\circ} \mathrm{C}$, an aqueous solution of $\mathrm{Na}_{2} \mathrm{CO}_{3}(125 \mu \mathrm{L}, 20 \%$, w/v) was added, and the sample mixed again and incubated for an additional $55 \mathrm{~min}$ at $25^{\circ} \mathrm{C}$. Final dilutions of samples in the test tubes are given in Supporting Information. The absorbance at $765 \mathrm{~nm}\left(\mathrm{~A}_{765}\right)$ was measured on a Varian Cary 100 BIO UV-VIS spectrophotometer in a polystyrene cuvette with a $1 \mathrm{~cm}$ path length. Absorbance of the blank $(50 \mu \mathrm{L}$ of MilliQ water instead of the sample) was subtracted from the absorbance of sample (three parallels).

\section{5. The DPPH and ABTS Assays}

The DPPH and ABTS assays were performed according to a modification of the method of Brand-Williams et al. ${ }^{22}$ and $\mathrm{Re}$ et al., ${ }^{23}$ respectively. The $\mathrm{DPPH}^{\circ}$ solution was prepared in $\mathrm{MeOH}$ and diluted to the concentration that would give an absorbance of 2.4 at $520 \mathrm{~nm}$ in the $1 \mathrm{~cm}$ pathlength cuvette. The radical cation of ABTS, $\mathrm{ABTS}^{\circ+}$, was produced by reacting ABTS with $\mathrm{MnO}_{2}$ in aqueous solution followed by centrifugation and filtration. The $\mathrm{ABTS}^{-+}$solution was diluted with MilliQ water to the concentration that would give an absorbance of 2.4 at $734 \mathrm{~nm}$ in the $1 \mathrm{~cm}$ pathlength cuvette. All the solutions, buffers and solvents were incubated at $25{ }^{\circ} \mathrm{C}$ prior to analysis.

The assay solutions were prepared in $1.5 \mathrm{~mL}$ micro centrifuge tubes by mixing $\mathrm{DPPH}^{*}$ or $\mathrm{ABTS}^{*+}$ solution $(500 \mu \mathrm{L})$ with $450 \mu \mathrm{L}$ of MilliQ water, $\mathrm{MeOH}$, acetate buffer $(25 \mathrm{mM}, \mathrm{pH} 5.0)$ or phosphate buffer $(5 \mathrm{mM}, \mathrm{pH}$ 7.4) for the DPPH assay, and MilliQ water, acetate buffer ( $25 \mathrm{mM}, \mathrm{pH} 5.0$ ) or phosphate buffer (5 mM, pH 7.4) for the ABTS assay. The reactions were started by the addi- 
tion of $50 \mu \mathrm{L}$ of the sample solution into the assay medium, with thorough mixing. Final dilutions of samples in the test tubes are given in Supporting Information. Each sample was prepared in three parallels. After $60 \mathrm{~min}$ incubation at $25{ }^{\circ} \mathrm{C}$ the absorbance at $520 \mathrm{~nm}$ in the DPPH assay $\left(\mathrm{A}_{520}\right)$ and $734 \mathrm{~nm}$ in the ABTS assay $\left(\mathrm{A}_{734}\right)$ was measured on a Varian Cary 100 BIO UV-VIS spectrophotometer in a $1 \mathrm{~cm}$ cuvette. The measured absorbance was subtracted from the corresponding absorbance of the controls $(50 \mu \mathrm{L}$ of MilliQ water instead of the sample) after $60 \mathrm{~min}$ incubation. The data are expressed as d$\mathrm{A}_{520}$ or $\mathrm{dA}_{734}$, respectively.

The assay solutions for analysis of the reaction kinetics of investigated antioxidants with $\mathrm{DPPH}^{*}$ (in the mixture of $\mathrm{MeOH}$ and phosphate buffer $\mathrm{pH} 7.4$, and in Me$\mathrm{OH}$ ) and $\mathrm{ABTS}^{\circ+}$ (in phosphate buffer pH 7.4 and in water) radicals were prepared in $1 \mathrm{~cm}$ quartz cuvettes with the stopper to prevent evaporation, by mixing $\mathrm{DPPH}^{\circ}$ or ABTS $^{*+}$ solution $(500 \mu \mathrm{L})$ with $450 \mu \mathrm{L}$ of the selected solvent. The reaction was started by the addition of $50 \mu \mathrm{L}$ of the sample solution (final dilutions in the assay solutions are given in Supporting Information) into the assay medium and $\mathrm{A}_{520}$ and $\mathrm{A}_{734}$, respectively, were continuously monitored at $15 \mathrm{~s}$ intervals over $180 \mathrm{~min}$ on a Varian Cary 100 BIO UV-VIS spectrophotometer at $25^{\circ} \mathrm{C}$. The measured absorbances were subtracted from the corresponding absorbances of the controls at appropriate time points.

\section{6. Statistical Analysis}

All samples were prepared in triplicate (three infusions prepared on different days). Each sample was analysed in three parallels. The standard deviations in determined AOP for the parallels were $<5 \%$ and standard deviations in AOP for different sample preparations were $<15 \%$. The coefficient of variation (CV) and Pearson correlation coefficients ( $r$ ) were calculated with program Excel (Microsoft).

\section{Results and Discussion}

\section{1. AOP of Selected Drinks and Food Supplements Obtained by DPPH, ABTS and FC Assays}

The values of $\mathrm{A}_{765}, \mathrm{dA}_{520}$ and $\mathrm{dA}_{734}$ determined after 60 min of incubation at selected dilutions (Supporting Information) of investigated beverages and dietary supplements were used to calculate the AOP with the DPPH, ABTS and FC method (Figure 1). For the purpose of comparison, the results were normalized according to the reactivity of Trolox determined under the same conditions and expressed as mmol TE per g of dry matter, or per L of beverage. $^{13}$
From Figure 1 and considering the values for $\mathrm{CV}$ of AOPs (Table 1), the method for AOP determination is seen to have a large impact on the values obtained. Furthermore, differences within a single method reveal that the solvent influences the ability of antioxidants to scavenge chromogenic radicals. The notable differences in the determined AOP of investigated samples can be attributed to the fact that the reactivity of antioxidants depends largely on the interaction of antioxidants with the solvent i.e. H-bonds and deprotonation of phenolic $-\mathrm{OH}$ group that depends, besides on its $\mathrm{pKa}$, on the $\mathrm{pH}$ of the reaction medium. ${ }^{7,24}$ In such a complex system, the variety of interactions between the antioxidants that operate via different reaction mechanisms results in the specific overall effect. However, despite the significant differences between samples, some common features can be seen.

Table 1. Coefficients of variation (CV) for AOP of samples determined by DPPH, ABTS assays and all methods applied

\begin{tabular}{lccc}
\hline Sample & \multicolumn{3}{c}{ CV (\%) } \\
& DPPH & ABTS & all methods \\
\hline Green tea & 16 & 24 & 20 \\
Black tea & 23 & 26 & 24 \\
Green coffee & 58 & 32 & 51 \\
Roasted coffee & 50 & 31 & 43 \\
Cranberry & 49 & 36 & 46 \\
Cranberry with vit. C & 4 & 10 & 33 \\
Pale lager beer & 62 & 64 & 70 \\
Apple juice & 55 & 55 & 57 \\
\hline
\end{tabular}

In general, the highest AOP for the majority of antioxidants, with the exception of green and black teas, was determined in the FC assay, followed by ABTS and DPPH assays in buffer $\mathrm{pH} 7.4$ and in buffer $\mathrm{pH} 5$ and the smallest one determined in $\mathrm{MeOH}$ (DPPH) or water (ABTS). For systems with similar compositions of phenolic compounds, e.g. green and black tea and roasted and green coffee, the AOP dependences on reaction medium are also similar. In the reactions of green and roasted coffee antioxidants with chromogenic radicals the influence of the studied solvents on reactivity was much greater with the DPPH assay (more than $100 \%$ higher AOP in buffer $\mathrm{pH}$ 7.4 than in the other three solvents) than with the ABTS assay. The largest difference in AOP assessed by different methods in different media was observed for beer antioxidants, as compared with the other investigated samples, resulting in three-fold greater AOP determined at $\mathrm{pH} 7.4$ than in $\mathrm{MeOH}\left(\mathrm{DPPH}^{\circ}\right)$ and water $\left(\mathrm{ABTS}^{\circ+}\right)$. When considering the effects of the reaction conditions on absolute levels of measured AOPs, the results with apple juice are similar to beer.

Although the main purpose of our study was not to measure the "absolute" AOP, comparison of our results with those in the literature should be considered. The AOP 

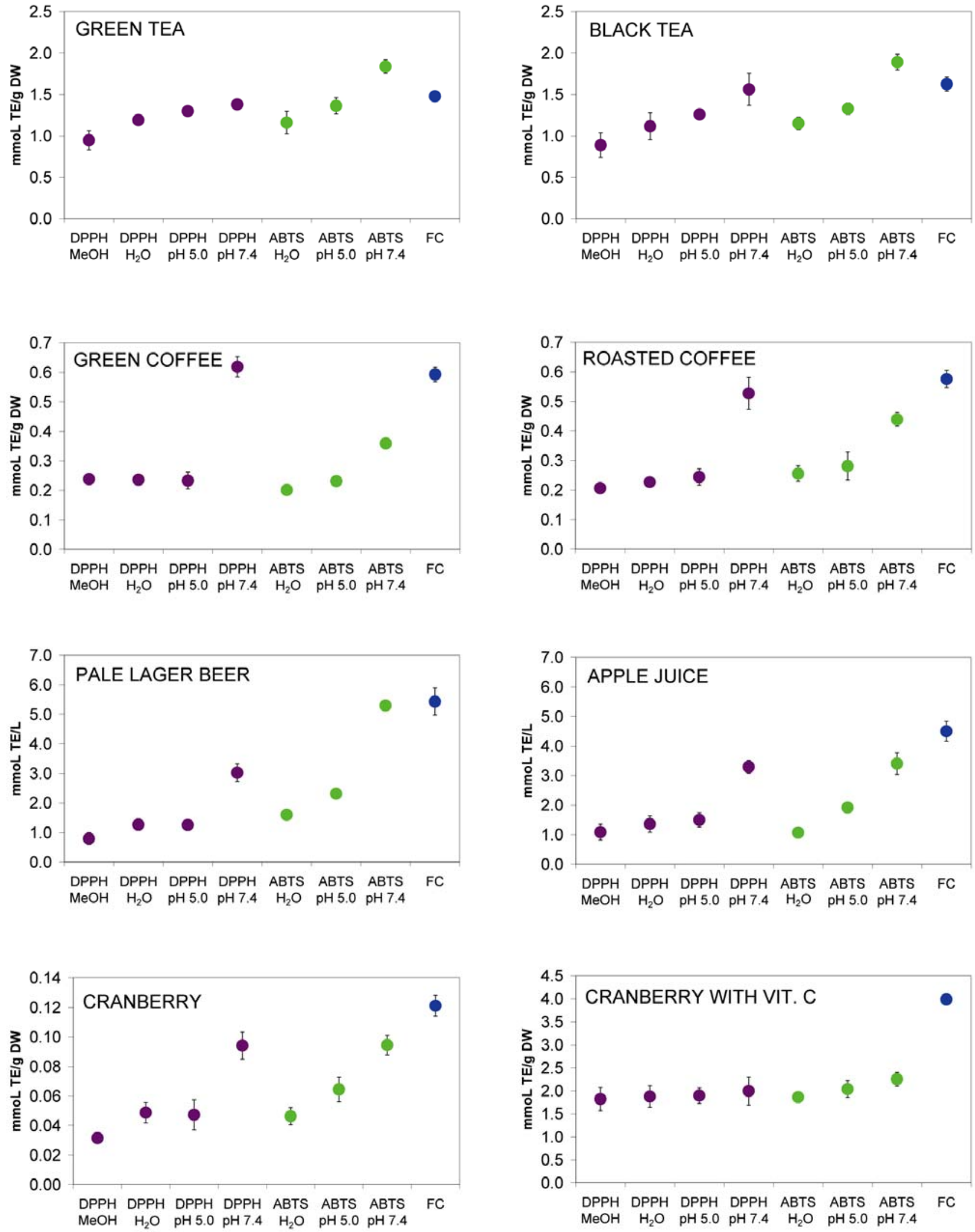

Figure 1. Antioxidant potential (AOP) of green tea, black tea, green coffee, roasted coffee, dietary supplement with dried cranberries, dietary supplement with dried cranberries and vitamin C, pale lager beer and apple juice in DPPH, ABTS and FC assays. The AOPs were determined after 60 min incubation of the properly diluted sample with the probe at $25^{\circ} \mathrm{C}$ in the particular solvent. They are expressed as Trolox equivalents in mmol/g of dry weight or $\mathrm{mmol} / \mathrm{L}$ of beverage. 
in original papers was normalized according to the reactivity of Trolox. ${ }^{13}$ The results reveal that the AOP values determined in our study are similar to those published elsewhere. ${ }^{15,16,18-20,25,26}$ In general, the highest AOP values determined by these authors were those determined using the FC method. This is consistent with the results of our study. It should be noted that the DPPH and ABTS assays in their studies were conducted in $\mathrm{MeOH}$ or in water, where we have also obtained lower AOP values than in the FC assay, too.

Comparison of values of AOP for food supplements, for dried cranberries and for dried cranberries with added vitamin $\mathrm{C}$, shows significant differences in absolute AOP values as well as in the influence of the solvent on the obtained AOP. The AOP of dried cranberries with added vit. $\mathrm{C}$ is almost two orders of magnitude higher than that of dried cranberry fruits, which in comparison to literature AOP data is of similar range though somewhat lower, ${ }^{17,27}$ most probably due to losses incurred during drying and storage, since the published data were obtained by analysing fresh fruit. The labelled content of ascorbic acid (AA) in the enriched cranberry food supplement amounts to $1.4 \mathrm{mmol} / \mathrm{g}$. Since Trolox and AA have similar molar reactivities in reactions with chromogenic radicals, ${ }^{13}$ it can be estimated that approx. $75 \%$ of AOP of investigated sample can be attributed to the AA. The large contribution of AA to the AOP of dried cranberries with added vit. $\mathrm{C}$ is reflected in the results obtained by FC assay, being twofold greater than those obtained by chromogenic radicals, as was observed for AA. ${ }^{13}$

\section{2. The Influence of Solvent on the Kinetics of Reaction of Antioxidants with ABTS ${ }^{\circ+}$ and DPPH* Radicals in Selected Drinks and Food Supplements}

The kinetics of reaction of antioxidants in selected samples with chromogenic radicals were analyzed in solvents giving the lowest (water for $\mathrm{ABTS}^{*+}$ or $\mathrm{MeOH}$ for $\mathrm{DPPH}^{\circ}$ ) and the highest (buffer $\mathrm{pH} 7.4$ for both, $\mathrm{ABTS}^{\circ+}$ and $\mathrm{DPPH}^{\circ}$ ) values of AOP after $60 \mathrm{~min}$ incubation. In order to compare the influence of incubation time on the value of $\mathrm{AOP}$, the $\mathrm{dA}_{520}$ and $\mathrm{dA}_{734}$ values determined at $15 \mathrm{~s}$ intervals were normalized to the corresponding values obtained after 60 min incubation of the selected sample with chromogenic radical in a particular solvent. The determined value of AOP depends greatly on the time of incubation (Figure 2), the effect being dependent on the sample, the type of assay and the solvent. However, for both tests the shape of curves reveals a fast phase followed by a slow one.

The fast phase, often completed in the range of seconds, is mainly attributable to the oxidation of existing phenolic -OH groups. ${ }^{12,28-31}$ The rate constants however depend greatly on the type of antioxidant and the solvent composition. ${ }^{3,12}$ In the present section we have not focused on the kinetics of the fast phases but rather on the amplitude that is directly proportional to the determined AOP, in order to show how incubation time influences its value. For both chromogenic radicals, with the exception of cranberry extract, beer and apple juice analyzed with $\mathrm{DPPH}^{*}$ radical in $\mathrm{MeOH}$, at least $50 \%$ of the "60 min" amplitude was reached after 1 min incubation.

At prolonged incubation times the kinetic profiles for the ABTS assays in buffer $\mathrm{pH} 7.4$ and in water are similar. However, it is important to note that, despite similar kinetic profiles, the calculated AOP for all samples is much higher in buffer pH 7.4 than in water (Figure 1). For beer, where, as compared to other samples, the largest difference in AOP determined by ABTS assays in water and buffer pH 7.4 was observed after $60 \mathrm{~min}$ (3.3-fold), the difference in AOP would be even larger if AOP was calculated after prolonged incubation.

Comparison of kinetic profiles for DPPH assays in $\mathrm{MeOH}$ and buffer $\mathrm{pH} 7.4$ reveals the same pattern for all analysed samples. The kinetics are much faster at $\mathrm{pH} 7.4$ and, for green tea and coffee, the absorbance virtually levels off after $30 \mathrm{~min}$, and only minor changes are observed up to $3 \mathrm{~h}$ incubation. In contrast to the DPPH assay at $\mathrm{pH} 7.4$, the kinetics in $\mathrm{MeOH}$ are much slower and AOP depends greatly on the time of incubation. It should be stressed that a large relative AOP increase after prolonged incubation in $\mathrm{MeOH}$ does not mean that $\mathrm{AOP}$ in $\mathrm{MeOH}$ is higher than in buffer $\mathrm{pH}$ 7.4. For the majority of samples, AOP determined after 60 min incubation with DPPH in buffer pH 7.4 is $\approx 3$-fold that in $\mathrm{MeOH}$ (Figure 1). Generally most of the amplitude of the slower phase can be attributed to secondary modifications of partially oxidized polyphenols and formation in the test tube of compounds with antioxidant properties. ${ }^{32}$ It is known that oxidative cross-coupling that leads to the formation of dimers some, of which possess radical scavenging activity themselves, can contribute significantly to the overall AOP. ${ }^{6,33}$ However, even for an early stage, the contribution to the initial amplitude of antioxidants formed from partially oxidized polyphenols cannot be neglected, especially for the solvents that increase the reaction rates. The presence in the sample of mixtures of antioxidants that differ in rate constant for their reaction with chromogenic radicals and have different propensities for secondary transformations undoubtedly results in a complex kinetic profile, as has been observed, even when oxidation of model compounds was analyzed. 6,34

The solvent type is responsible for electron and/or hydrogen atom transfer which are characteristic not only in sequential proton loss electron transfer (SPLET) but also in hydrogen atom transfer, proton-coupled electron transfer and other mechanisms of the reaction of antioxidants with radicals. ${ }^{35}$ Moreover, the change of hydrogen ion concentration (different buffer $\mathrm{pH}$, or acidic methanol) may alter the dominant reaction mechanism. 

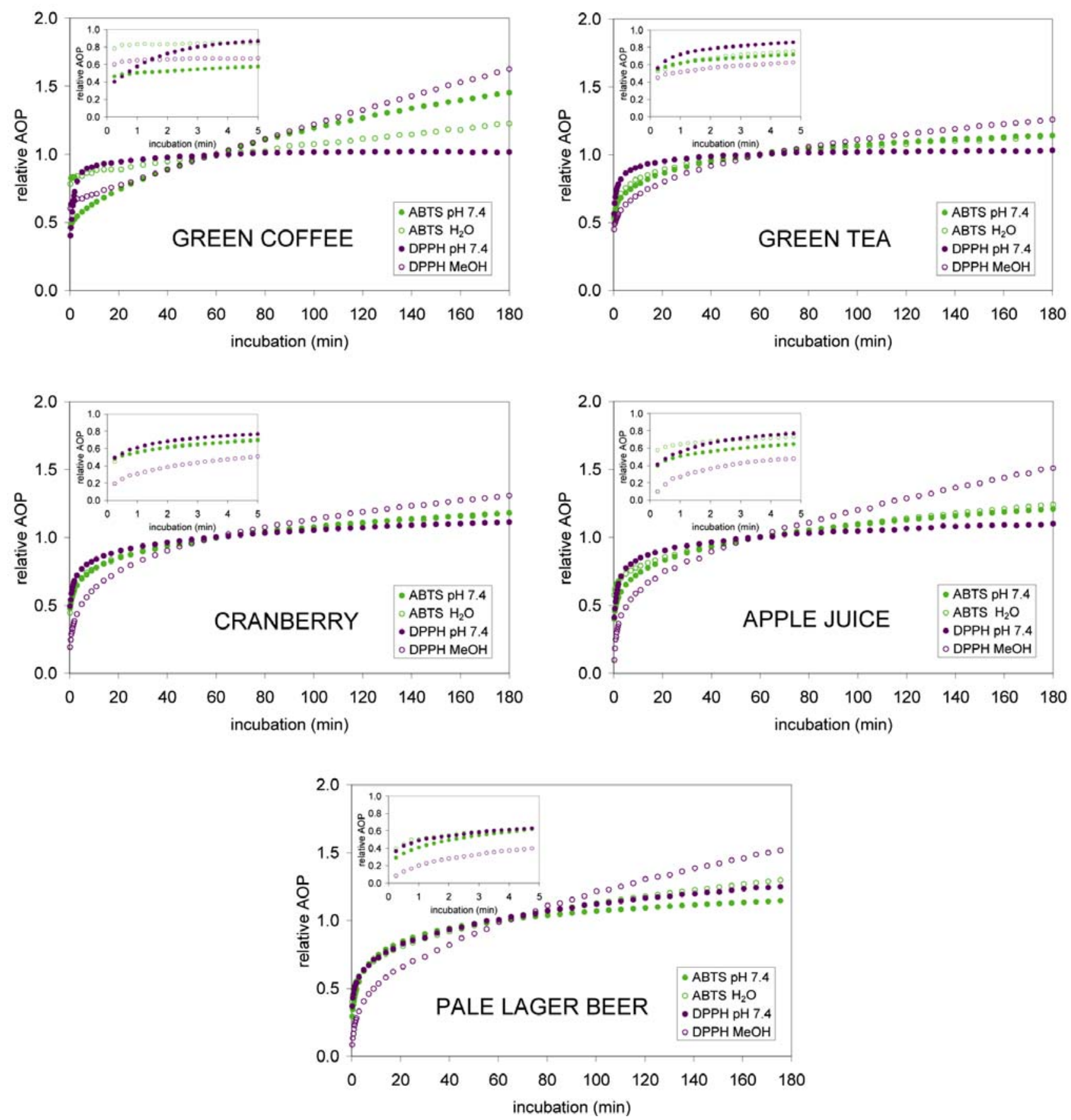

Figure 2. Influence of incubation time at $25^{\circ} \mathrm{C}$ on the antioxidant potential (AOP) determined for green tea, green coffee, dietary supplement with dried cranberries, pale lager beer and apple juice in DPPH assay in methanol or DPPH assay in the mixture of methanol and buffer pH 7.4, and ABTS assays in MilliQ water or buffer $\mathrm{pH}$ 7.4. The $\mathrm{dA}_{520}$ and $\mathrm{dA}_{734}$ values obtained at certain time point were divided by $\mathrm{dA}_{520}$ or $\mathrm{dA}_{734}$ values measured after $60 \mathrm{~min}$ incubation in the particular solvent to give the relative AOP at a certain time point in comparison to the 60 min incubation for each of the four assays.

SPLET, which includes oxidation of the deprotonated form of the phenolic compound, $\mathrm{ArO}^{-}$to $\mathrm{ArO}^{\circ}$, is the predominant reaction mechanism of the phenolic compounds with different radicals in protic solvents. ${ }^{28,36-38}$ Since the oxidation of the deprotonated form of phenolic compounds $\left(\mathrm{ArO}^{-} \rightarrow \mathrm{ArO}^{\circ}+\mathrm{e}^{-}\right)$(very fast) is preferred over that of the corresponding phenol $\left(\mathrm{ArOH} \rightarrow \mathrm{ArO}^{\circ}+\right.$ $\mathrm{H}^{+}+\mathrm{e}^{-}$) (slow), in aqueous medium which supports the deprotonation of the phenol well and has higher H-bond accepting ability than $\mathrm{MeOH}$, the oxidation of phenols is expected to be faster than in pure $\mathrm{MeOH}^{7}$ That is most likely the reason for the smaller initial amplitude observed 
in $\mathrm{MeOH}$ (Figure 2). Solvents with high H-bond accepting ability strongly decrease the rate of abstracting hydrogen from $\mathrm{ArOH}$ and thus favour electron transfer processes from $\mathrm{ArO}^{-28,39}$ The AOP at neutral and basic $\mathrm{p}$ $\mathrm{H}$, is expected to be higher than that in mildly acidic $\mathrm{pH}$ or absence of buffer (Figure 1), bearing in mind that the acid/base equilibrium of the $-\mathrm{OH}$ group at higher $\mathrm{pH}$ is shifted to the deprotonated form, $\mathrm{ArO}^{-}$. It must be considered that not only a difference in the reaction rates but also modifications of partially oxidized polyphenols, resulting in the formation of secondary antioxidants, contribute to AOP.

The large influence of incubation time on the determined AOP with DPPH in MeOH, which is the most common solvent for this type of assay, points to the importance of controlling time and temperature in the experiment. The fact that the AOP depends greatly on experimental conditions is often neglected and many papers, in which AOP of various samples is determined, are published each year without a detailed description of the experimental conditions.

Despite the above noted limitations, methods for evaluating AOP will remain useful tools for rapid assessment of the amounts of redox active compounds in complex matrices. There is, nevertheless, sufficient evidence that assays for estimating AOP should be performed under controlled and well defined conditions, that are properly described in the methods section, in order to enable comparison with published results.

\section{3. Correlation Between AOPs Determined in Different Assays and Different Solvents}

Pearson correlation coefficients of AOPs for eight samples, determined in different assays and solvents, are listed in Table 2. In general the $r$ values are large and for only four combinations are the values not significant at $\alpha$ $=0.05$. The strong correlations have also been observed for combinations of FC, ABTS and DPPH assays of food samples. ${ }^{15,40}$ The correlations in our study that are not sig- nificant at $\alpha=0.05$ were determined for DPPH in $\mathrm{MeOH}$ when correlated to the AOP obtained in DPPH and ABTS assays at $\mathrm{pH} 7.4$ and FC assay. This is to be expected as the reactivity of ionized polyphenols in neutral and basic $\mathrm{pH}$ solutions is certainly different from that in $\mathrm{MeOH}$. The correlation within ABTS and DPPH assays performed in different solvents was weakest for both radicals when AOP was determined at $\mathrm{pH}$ 7.4. Higher $\mathrm{r}$ values were observed when DPPH and ABTS assays at $\mathrm{pH} 7.4$ were correlated to the FC assays than to the AOP values determined with chromogenic radicals in other solvents.

It should be stressed out that overall good correlation coefficients do not guarantee that AOPs determined by the two methods give similar TE values. For example, we have found strong correlation $(\mathrm{r}=0.94$; significant at $\alpha=0.001$ ) between AOP determined with ABTS assay in pH 5 buffer and AOP determined by FC assay, but $90 \%$ higher AOP was on average determined by FC assay.

\section{4. Correlation Between AOPs Determined for Complex Samples and Model Antioxidants}

In order to determine whether the influence of type of assay and of solvent composition on the reactivity of a model antioxidant is similar to that for complex samples where particular model antioxidant is a major redox active compound correlation analyses were performed (Table 3 ). The reactivities of model antioxidants that are important constituents of samples included in this study have been analyzed under the same conditions. ${ }^{13}$ For both tea samples the highest $r$ values were determined with catechin $(\mathrm{CTH})$ and epigallocatechin gallate (EGCG) which are major constituents of tea polyphenols. ${ }^{16,41}$ Additionally, for gallic acid (GA), that is a constituent of EGCG, the best correlation, although not statistically significant, was observed with tea samples. High correlations have been observed for green and roasted coffee with chlorogenic (CGA) and caffeic acids (CA) that are major polyphenolic compounds in coffee..$^{20,42}$ Cranberries contain a complex mixture of poylphenols with flavonoids as major con-

Table 2. The values of Pearson correlation coefficient for correlation between antioxidant potentials determined in various assays

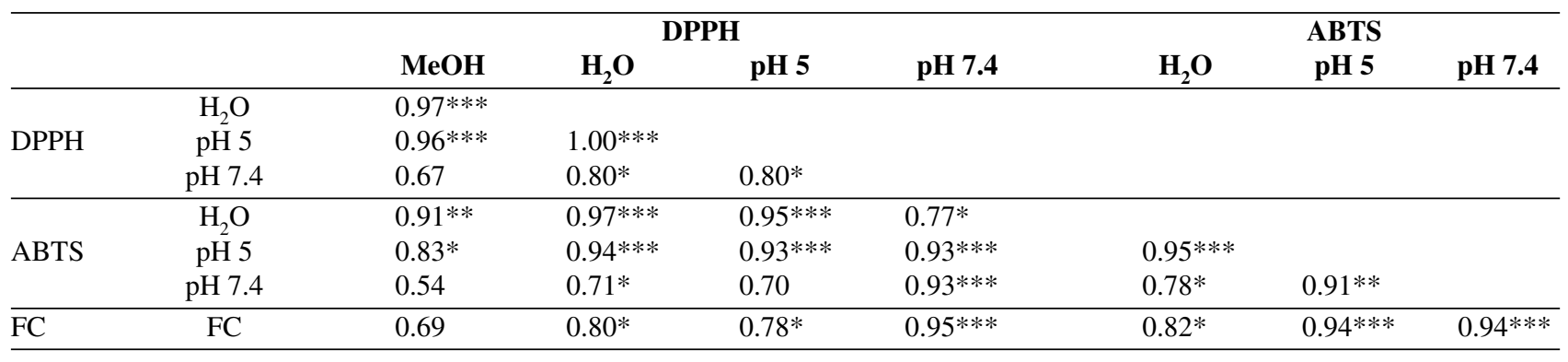

*** values are significant at the $\alpha=0.001$ level, ** are significant at the $\alpha=0.01$ and $*$ are significant at the $\alpha=0.05$ level 
Table 3. The values of Pearson correlation coefficient for antioxidant potentials of food samples and model polyphenols determined in various assays

\begin{tabular}{lllllll}
\hline & GA & CGA & CTH & EGCG & CA & AA \\
\hline Green tea & 0.64 & 0.42 & $0.85^{* *}$ & $0.75^{*}$ & 0.26 & 0.27 \\
Black tea & 0.46 & 0.63 & $0.92^{* *}$ & $0.76^{*}$ & 0.50 & 0.40 \\
Green coffee & -0.33 & $0.99^{* * *}$ & 0.66 & 0.47 & $0.96^{* * *}$ & 0.67 \\
Roasted coffee & -0.08 & $0.95^{* * *}$ & $0.82^{*}$ & 0.54 & $0.86^{* *}$ & 0.70 \\
Cranberry & 0.07 & $0.88^{* *}$ & $0.86^{* *}$ & 0.53 & $0.75^{*}$ & $0.73^{*}$ \\
Cranberry with vit. C & -0.21 & $0.71^{*}$ & 0.46 & -0.08 & 0.50 & $0.98^{* * *}$ \\
Pale lager beer & 0.33 & 0.70 & $0.83^{*}$ & 0.53 & 0.51 & 0.66 \\
Apple juice & 0.04 & $0.89 * *$ & $0.81^{*}$ & 0.52 & $0.74 *$ & $0.75^{*}$ \\
\hline
\end{tabular}

*** values are significant at the $\alpha=0.001$ level, ** are significant at the $\alpha=0.01$ and $*$ are significant at the $\alpha=0.05$ level

stituents, ${ }^{27,43}$ which can be related to the high correlation with CTH. The fact that AA is the predominant antioxidant in vit. $\mathrm{C}$ enriched cranberry supplement is reflected in the excellent correlation with AA. For apple juice ${ }^{44,45}$ and beer, ${ }^{18,46}$ in which the major polyphenols are hydroxycinnamic acid and flavan-3-ols, the best correlation is observed with model antioxidants within these groups.

The data presented in Table 3 clearly show that the type of assay and the solvent composition have similar influences on the reactivity of a particular antioxidant, either pure or as part of a complex matrix.

\section{Conslusions}

Spectrophotometric methods for assessing the amount of redox active compounds in complex matrices as DPPH, ABTS and FC assays are widespread and are applied in areas of agricultural and food science, chemistry and pharmacy. We have shown that the small variations in experimental protocols that are often encountered in the literature can result in considerable differences in the reactivity of antioxidants in food samples and dietary supplements. This confirms that antioxidant activity/potential is not an inherent property of a compound but is strongly influenced by the nature of the reactive target species as well as by the environment in which the reaction takes place.

\section{Abbreviations}

A, absorbance; AA, ascorbic acid; $\mathrm{ABTS}^{\circ+}, 2,2^{\prime}$-azino-bis-3-ethylbenzothiazoline-6-sulfonic acid; AOP, antioxidant potential; $\mathrm{ArOH}$, phenolic compound; $\mathrm{CA}$, caffeic acid; CGA, chlorogenic acid; $\mathrm{CTH}$, catechin; CV, coefficient of variation; DPPH', 2,2-diphenyl-1-picrylhydrazyl; EGCG, epigallocatechin gallate; FC, Folin-Ciocalteu; GA, gallic acid; $\mathrm{MeOH}$, methanol; r, Pearson correlation coefficient; SPLET, sequential proton loss electron transfer; TE, Trolox equivalents

\section{Acknowledgments}

This work was supported by Slovenian Research Agency contract P4-0121. The authors would like to thank Roger H. Pain for his valuable suggestions and discussion of the paper.

\section{References}

1. S. Chanda, R. Dave, Afr. J. Microbiol. Res. 2009, 3 (13), 981-996.

2. R. G. Berger, S. Lunkenbein, A. Ströhle, A. Hahn, Crit. Rev. Food Sci. Nutr. 2012, 52, 162-171. https://doi.org/10.1080/10408398.2010.499481

3. J. Xie, K. M. Schaich, J. Agric. Food Chem. 2014, 62 (19), 4251-4260. https://doi.org/10.1021/jf500180u

4. M. C. Foti, J. Agric. Food Chem. 2015, 63, 8765-8776. https://doi.org/10.1021/acs.jafc.5b03839

5. M. Foti, G. Ruberto, J. Agric. Food Chem. 2001, 49, 342348. https://doi.org/10.1021/jf0006527

6. P. Goupy, C. Dufour, M. Loonis, O. Dangles, J. Agric. Food Chem. 2003, 51 (3), 615-622. https://doi.org/10.1021/jf0259381

7. G. Litwinienko, K. U. Ingold, Acc. Chem. Res. 2007, 40, 222-230. https://doi.org/10.1021/ar0682029

8. L. Bertalanič, T. Košmerl, N. Poklar Ulrih, B. Cigić, J. Agric. Food Chem. 2012, 60 (50), 12282-12288. https://doi.org/10.1021/jf3041512

9. A. L. Dawidowicz, D. Wianowska, M. Olszowy, Food Chem. 2012, 131 (3), 1037-1043. https://doi.org/10.1016/j.foodchem.2011.09.067

10. A. L. Dawidowicz, M. Olszowy, Eur. Food Res. Technol. 2013, 236 (6), 1099-1105. https://doi.org/10.1007/s00217-013-1982-1

11. J. Anissi, M. El Hassouni, A. Ouardaoui, K. A. Sendide, Food Chem. 2014, 150, 438-447. https://doi.org/10.1016/j.foodchem.2013.11.009

12. T. Prevc, N. Šegatin, N. Poklar Ulrih, B. Cigić, Talanta 2013, 109, 13-19.

https://doi.org/10.1016/j.talanta.2013.03.046 
13. H. Abramovič, B. Grobin., N. Poklar Ulrih, B. Cigić, Submitted for publication.

14. A. L. Dawidowicz, M. Olszowy, Eur. Food Res. Technol. 2010, 231 (6), 835-840. https://doi.org/10.1007/s00217-010-1333-4

15. A. Floegel, D.-O. Kim, S.-J. Chung, S. I. Koo, O. K. Chun, J. Food Compos. Anal. 2011, 24 (7), 1043-1048. https://doi.org/10.1016/j.jfca.2011.01.008

16. P. Carloni, L. Tiano, L. Padella, T. Bacchetti, C. Customu, A. Kay, E. Damiani, Food Res. Int. 2013, 53 (2), 900-908. https://doi.org/10.1016/j.foodres.2012.07.057

17. J. Namiesnik, K. Vearasilp, M. Kupska, K.-S. Ham, S.-G. Kang, Y.-K. Park, D. Barasch, A. Nemirovski, S. Gorinstein, Eur. Food Res. Technol. 2013, 237 (5), 819-829. https://doi.org/10.1007/s00217-013-2041-7

18. S. S. Mitić, D. Đ. Paunović, A. N. Pavlović, S. B. Tošić, M. B. Stojković, M. N. Mitić, Int. J. Food Prop. 2014, 17 (4), 908-922. https://doi.org/10.1080/10942912.2012.680223

19. C. S. G. Kitzberger, M. B. D. Scholz, M. D. Benassi, Food Res. Int. 2014, 61, 61-66. https://doi.org/10.1016/j.foodres.2014.04.031

20. T. Pilipczuk, B. Kusznierewicz, D. Zieliñska, A. Bartoszek, J. Food Sci. Technol. 2015, 52, 5736-5744. https://doi.org/10.1007/s13197-014-1646-6

21. T. Gutfinger, J. Am. Oil Chem. Soc. 1981, 58, 966-968. https://doi.org/10.1007/BF02659771

22. W. Brand-Williams, M. E. Cuvelier, C. Berset, Lebensm. Wiss. Technol. 1995, 28, 25-30. https://doi.org/10.1016/S0023-6438(95)80008-5

23. R. Re, N. Pellegrini, A. Proteggente, A. Pannala, M. Yang, C. Rice-Evans, Free Radic. Biol. Med. 1999, 26 (9-10), 12311237. https://doi.org/10.1016/S0891-5849(98)00315-3

24. M. Musialik, G. Litwinienko, Org. Lett. 2005, 7 (22), 49514954. https://doi.org/10.1021/ol051962j

25. J. Lachman, M. Šulc, J. Sus, O. Pavlíková, Hort. Sci. 2006, 33 (3) 95-102.

26. I. Juranović, Cindrić, M. Kunštić, M. Zeiner, G. Stingeder, G. Rusak, Croat. Chem. Acta 2011, 84 (3), 435-438.

27. E. J. Borowska, B. Mazur, R. G. Kopciuch, B. Buszewski, Food Technol. Biotechnol. 2009, 47 (1), 56-61.

28. M. C. Foti, C. Daquino, C. Geraci, 2003, J. Org. Chem. 69 (7), 2309-2314. https://doi.org/10.1021/jo035758q

29. O. Friaa, D. Brault, Org. Biomol. Chem. 2006, 4, 24172423. https://doi.org/10.1039/b602147f
30. R. B. Walker, J. D. Everette, J. Agric. Food Chem. 2009, 57, 1156-1161. https://doi.org/10.1021/jf8026765

31. M. Musialik, R. Kuzmicz, T. S. Paw ${ }^{3}$ owski, G. Litwinienko, J. Org. Chem. 2009, 74 (7), 2699-2709. https://doi.org/10.1021/jo802716v

32. H. Hotta, S. Nagano, M. Ueda, Y. Tsujino, J. Koyama, T. Biochim. Biophys. Acta 2002, 1572, 123-132. https://doi.org/10.1016/S0304-4165(02)00285-4

33. X. L. Jin, R. T. Yang, Y. J. Shang, F. Dai, Y. P. Qian, L. X. Cheng, B. Zhou, Z. L. Liu, Chin. Sci. Bull. 2010, 55, 28852890. https://doi.org/10.1007/s11434-010-3064-0

34. P. Terpinc, H. Abramovič, Food Chem. 2010, 121, 366-371. https://doi.org/10.1016/j.foodchem.2009.12.037

35. A. L. Dawidowicz, M. Olszowy, Talanta 2012, 97, 312-317. https://doi.org/10.1016/j.talanta.2012.04.036

36. C. Iuga, J. R. Alvarez-Idaboy, N. Russo, J. Org. Chem. 2012, 77 (8), 3868-3877. https://doi.org/10.1021/jo3002134

37. R. L. Prior, X. Wu, K. Schaich, J. Agric. Food Chem. 2005, 53, 4290-4302. https://doi.org/10.1021/jf0502698

38. Y. J. Shang, B. Y. Liu, M. M. Zhao, Czech J. Food Sci. 2015, 33, 210-216. https://doi.org/10.17221/611/2014-CJFS

39. M. Bietti, M. Salamone, G.A. DiLabio, S. Jockusch, N.J. Turro, Org. Chem. 2012, 77, 1267-1272 https://doi.org/10.1021/jo201454c

40. S. Dudonné, X. Vitrac, P. Coutière, M. Woillez, J. M. Mérillon, J. Agric. Food Chem. 2009, 57 (5), 1768-1774. https://doi.org/10.1021/jf803011r

41. Y. Zuo, H. Chen, Y. Deng, Talanta 2002, 57 (2), 307-316. https://doi.org/10.1016/S0039-9140(02)00030-9

42. C. L. Ky, J. Louarn, S. Dussert, B. Guyot, S. Hamon, M. Noirot, Food Chem. 2001, 75, 223-230. https://doi.org/10.1016/S0308-8146(01)00204-7

43. E. Pappas, K. M. Schaich, Crit. Rev. Food Sci. Nutr. 2009, 49, 741-781.

https://doi.org/10.1080/10408390802145377

44. K. Kahle, M. Kraus, E. Richling, Mol. Nutr. Food Res. 2005, 49, 797-806.

https://doi.org/10.1002/mnfr.200500064

45. M. Ceymann, E. Arrigoni, H. Schärer, A. Bozzi Nising, R. F. Hurrell, J. Food Compos. Anal. 2012, 26 (1-2), 128-135. https://doi.org/10.1016/j.jfca.2011.12.002

46. M. Dvorakova, P. Hulin, M. Karabin, P. Dostalek, Czech J. Food Sci. 2007, 25, 182-188.

\section{Povzetek}

Antioksidativni potencial (AOP) ni samo lastnost analiziranega vzorca, ampak je v veliki meri odvisen tudi od uporabljene metodologije. Na primeru kromogenih radikalov 2,2'-azino-bis(3-etilbenzotiazolin-6-sulfonske kisline) $\left(\mathrm{ABTS}^{\bullet+}\right)$, 2,2-difenil-1-pikrilhidrazila (DPPH') in Folin-Ciocalteu (FC) metode smo pokazali, kako izbor metode in sestava topila, v katerem poteka reakcija, vplivata na določeno vrednost AOP kave, čaja, piva, jabolčnega soka in prehranskih dopolnil. V splošnem smo največje AOP vrednosti določili s FC metodo. Reakcijski medij ima velik vpliv na določeno vrednost AOP s kromogenima radikaloma, saj smo v pufru s pH 7,4 določili nekajkrat večji AOP kot v vodi ali metanolu. Izbor metode in sestava reakcijskega medija imata podoben vpliv na reaktivnost posameznega antioksidanta, tako čistega kot v mešanici z ostalimi antioksidanti. AOP je močno odvisen tudi od časa inkubacije, toda različno za posamezne vzorce in izbrane metode. 